術後, 肝末梢部多発生 A-P shunt が消失した肝囊胞腺癌の 1 例

\begin{tabular}{|c|c|c|c|c|c|c|c|}
\hline 松下 & 文昭 & 横山 & 化 & 鵜浦 & 雅志 & 田中 & 延善 \\
\hline 加登 & 康洋 & 小林 & 健一 & 服部 & 信*1 & 新村 & 康二*2 \\
\hline 角谷 & 真澄 & 松井 & 修*3 & 水上 & 勇治*4 & 中沼 & 安二*5 \\
\hline
\end{tabular}

要 旨：画像診断にて腫湯性襄胞が疑われ，合併した胆道系酵素の上昇，および A-P shuntが，

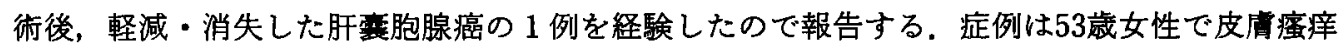
感のため当科に入院した。肝機能検査では, 胆道系酻素の上昇を認め, 腹部ェコー・CTでは, 肝門部を中心に, 壁の一部に結節状隆起を有する巨大な裹胞と, 肝内胆管の拡張がみられた。 さらに，血管造影上は，門脈の圧排と肝末梢部に多発した A-P shunt が認められた。摘出標本 の組織所見では，襄胞内面顆粒状隆起部に悪性像が認められ，肝襄胞腺癌と診断された。術後,

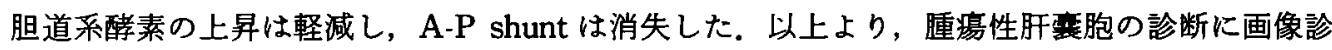
断が有用であり，また，巨大な震胞による門脈・胆道系への mass effectによって，transsinusoidal type の A-P shunt, および胆道系酵素の上昇を主とした肝機能検查異常が生じ得る と考えられた.

索引用語：肝襄胞 肝蓑胞腺癌 A.P shunt

\section{はじめに}

肝豪胞腺癌は現在までに約30例が報告され，その病 理組織学的特徵が明らかにされつつあるが, 臨床検査 上は特徴的なものはなく，正確な術前診断は困難であ $3^{1-10)}$.

また，血管造影法の進歩により種々の肝疾患におけ る Arterioportal shunting (A.P shunt) の存在が明ら かとなってきたが，その成立機序は未だ十分解明され ていない.

今回著者らは, 腹部エコー・CT にて畽湯性衰胞が疑 われ，合併した胆道系酵素の上昇を主とした肝機能検 查異常および A.P shunt が售胞摘出後に軽減・消失し た肝震胞腺癌の 1 例を経験したので報告する.

\section{症例}

症例 : 53藏, 女性, 主婦.

主訴：皮席瘦痒感。

家族歴：特記すべきことなし。

*1 金沢大学第 1 内科

*2 金沢大学第 2 外科

*3 金沢大学放射線科

*4 金讯大学医学部附属病院中央検査部

*5 金沢大学第 2 病理

〈受付日59年12月 5 日 $>$
既往歴：特記すべきことなし。

現病歴：昭和57年 5 月頃，带を締めると冷感を覚え たため近医を受診したところ，肝腫大と肝機能異常を 指摘された。同年 7 月より皮膚瘦痒感を認めるよらに なり，同年10月 5 日，精査加療のため入院となった。 この間, 黄疸, 体重减少, 食欲不振等は認めていない。

入院時現症：身長 $152.5 \mathrm{~cm}$, 体重 $53.5 \mathrm{~kg}$, 血比 $152 /$ $72 \mathrm{mmHg}$, 脈拍78/分整, 皮庙に黄色腫, 手掌紅就, ク モ状血管腫は認めなかった。結膜に貧血・黄庭はなかっ た。胸部では打聴診上異常なく，腹部では肝を正中線 上で 4 横指, 右季肋下で 3 横指触知した。肝の性状は, 辺縁鈍, 表面平滑, 弾性軟で, 軽度の圧痛を認めた。 脾は触知せず，腹水・浮腫は認めなかった，神経学的 にも異常は認めなかった。

入院時検查成績 (Table 1)：高色素性負血を認め, 血沈は $43 \mathrm{~mm} / \mathrm{hr}$ と中等度に元進していた. T. bilirubin は $2.19 \mathrm{mg} / \mathrm{d} l$ と軽度に上年し，Al-P $1,328 \mathrm{IU} / \mathrm{L}$, $\gamma$-GTP 789IU/L, GOT 280IU/L, GPT 281IU/L と胆 道系酳素の上昇が優位の肝機能検査異常を認めた。 T. cholesterol は324mg/d $l$ と上昇し, ICG (15分値) $16.5 \%$, BSP (45分値) $43.5 \%$ と停滞を示した。 抗ミ トコンドリフ抗体は陰性で, IgM は $132 \mathrm{mg} / \mathrm{d} l$ と正常 範囲内であった，AFP，CEA は共に陰性であった。 
Table 1 Laboratory data on admission.

\begin{tabular}{|c|c|c|c|c|}
\hline \multicolumn{3}{|c|}{ Urinalysis } & GOT(IU/L) & 280 \\
\hline \multicolumn{2}{|c|}{ protein } & $(-)$ & GPT (IU/L) & 281 \\
\hline \multicolumn{2}{|c|}{ glucose } & $(-)$ & $\mathrm{LDH}(\mathrm{IU} / \mathrm{L})$ & 436 \\
\hline \multicolumn{2}{|c|}{ urobilinogen } & $( \pm)$ & Al-P(IU/L) & 1328 \\
\hline \multicolumn{2}{|c|}{ bilirubin } & $(-)$ & $\boldsymbol{\gamma}$-GTP(IU/L) & 789 \\
\hline \multicolumn{2}{|c|}{ O.B. } & $(-)$ & ZTT & 10.9 \\
\hline \multicolumn{2}{|c|}{ Stool O.B. } & $(-)$ & TTT & 2.0 \\
\hline \multicolumn{2}{|c|}{$\mathrm{RBC}\left(\times 10^{4}\right)$} & 321 & Amylase(IU/L) & 228 \\
\hline \multicolumn{2}{|c|}{$\mathrm{Hb}(\mathrm{g} / \mathrm{d} l)$} & 10.8 & T. cholesterol $(\mathrm{mg} / \mathrm{d} l)$ & 324 \\
\hline \multicolumn{2}{|c|}{$\mathrm{Ht}(\%)$} & 31.1 & ICG $15^{\prime}(\%)$ & 16.5 \\
\hline \multicolumn{2}{|l|}{ WBC } & 3300 & BSP $45^{\prime}(\%)$ & 43.5 \\
\hline \multicolumn{2}{|c|}{$\operatorname{Plts}\left(\times 10^{4}\right)$} & 11.5 & $\operatorname{AFP}(\mathrm{ng} / \mathrm{m} l)$ & 10 \\
\hline \multicolumn{2}{|c|}{$\mathrm{PT}(\mathrm{sec})$} & 12.4 & $\mathrm{CEA}(\mathrm{ng} / \mathrm{m} l)$ & 2.5 \\
\hline \multicolumn{2}{|c|}{ Fibrinogen $(\mathrm{mg} / \mathrm{d} l)$} & 280 & $\operatorname{ESR}(\mathrm{mm} / \mathrm{hr})$ & 43 \\
\hline \multicolumn{2}{|c|}{ HPT(\%) } & 115 & CRP & $(-)$ \\
\hline \multicolumn{2}{|c|}{$\mathrm{Fe}(\gamma / \mathrm{d} l)$} & 116 & RA & $(-)$ \\
\hline \multicolumn{2}{|c|}{ T.protein $(\mathrm{g} / \mathrm{d} l)$} & 7.0 & ANA & $(-)$ \\
\hline alb. & $(\%)$ & 59.6 & AMA & $(-)$ \\
\hline$\alpha_{1} g l$ & (\%) & 5.9 & ASMA & $(-)$ \\
\hline$\alpha_{2} g l$ & $(\%)$ & 8.8 & $\operatorname{IgG}(\mathrm{mg} / \mathrm{d} l)$ & 1660 \\
\hline$\beta g l$. & (\%) & 7.3 & $\operatorname{IgA}(\mathrm{mg} / \mathrm{d} l)$ & 226 \\
\hline rgl. & $(\%)$ & 18.4 & $\operatorname{IgM}(\mathrm{mg} / \mathrm{d} l)$ & 132 \\
\hline T.biliru & $\mathrm{g} / \mathrm{d} l)$ & 2.19 & $\mathrm{HBsAg}$ & $(-)$ \\
\hline D.biliru & $\mathrm{g} / \mathrm{d} l)$ & 0.93 & $\mathrm{HBsAb}$ & $(-)$ \\
\hline
\end{tabular}

入院後経過：肝重大, 胆道系醅素の上昇, 血沈穴進 等の所見より，肝胆道系の悪性尰湟が疑われ以下の検 索を行なった，腹部ェコーでは肝左葉内側区域から肝 門部にかけて，壁の一部に内腔に突出する結節状隆起 を有する径 $12 \times 10 \mathrm{~cm}$ の豪胞がみられ(Fig. 1-a)，肝内 胆管抾張所見も認められた (Fig. 1-b). 腹部 CT では 衰胞壁の石戻化と肝内胆管払張所見 (Fig. 2-a)，内腔

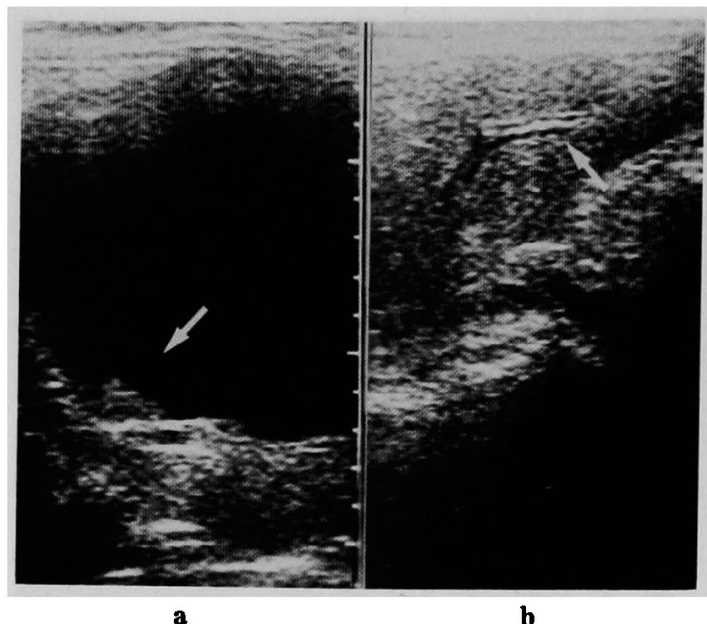

Fig. 1a Ultrasound shows a huge liver cyst with a mural nodular lesion (arrow).

b. Ultrasound shows dilated intrahepatic bile ducts (arrow).

に突出する結節状隆起 (Fig. 2-b) が認められた。選択 的肝動脈造影では，多中心性に末梢での A-P shunt が みられ，逆行性に門脈前枝が描出された。 また固有肝 動脈, 前区域動脈, 後区域動脈の王排・偏位が認めら れたが、いわゆる腫焬血管は認めず, Avascular lesion と考えられた（Fig. 3). 毛細管相では腫瘍は全く濃染 されず，薄い樭胞壁が描出されたのみであった。また， 右葉前区域には多発した A-P shuntによる濃染像が 多数認められた (Fig. 4). 上腸間膜動脈造影の門脈相 では, 肝門部門脈の王排・偏平化, 門脈前枝根部の王 排・张窄が認められ，右前下枝は全く描出されなかっ

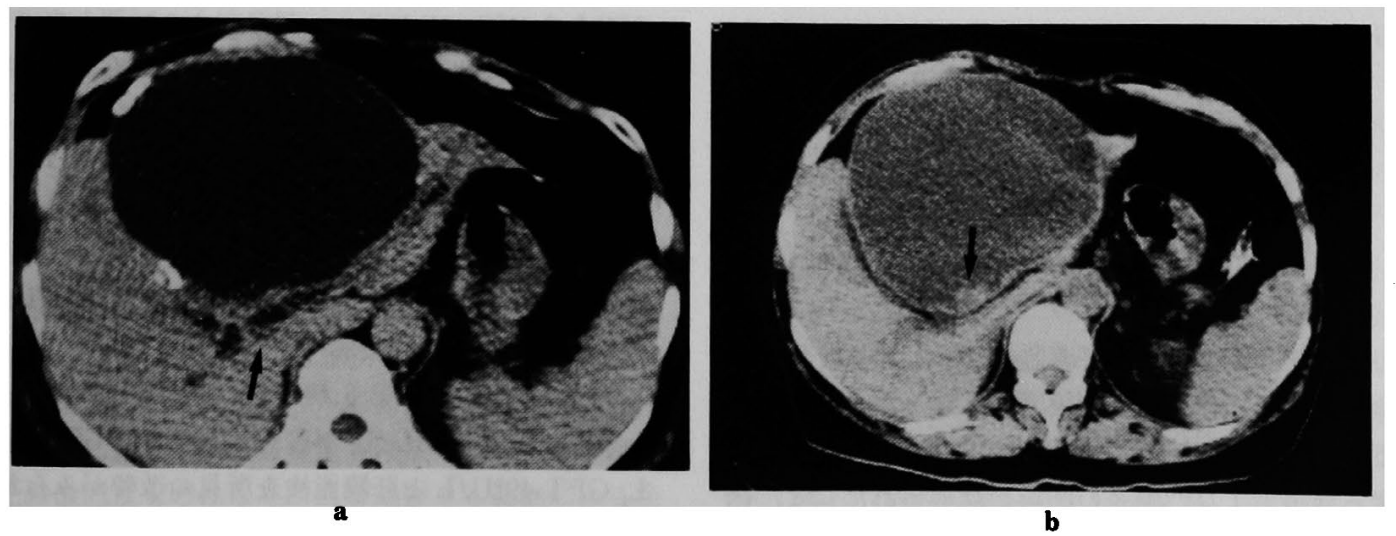

Fig. 2a CT scan shows calcifications of the cyst wall and dilated intrahepatic bile ducts (arrow).

b. CT scan shows a mural nodular lesion (arrow). 


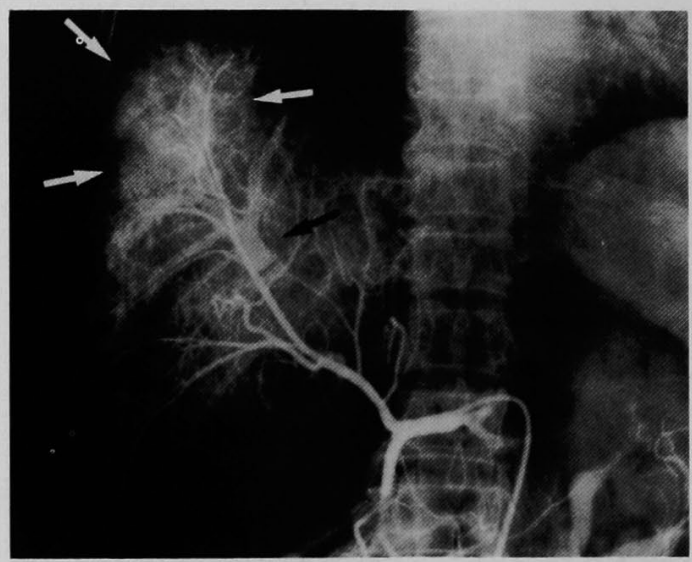

Fig. 3 Selective hepatic angiography shows multicentric arterioportal shuntings in the anterior segment of the liver (white arrows) and retrograde opacification of the anterior branch of the right portal vein (arrow).

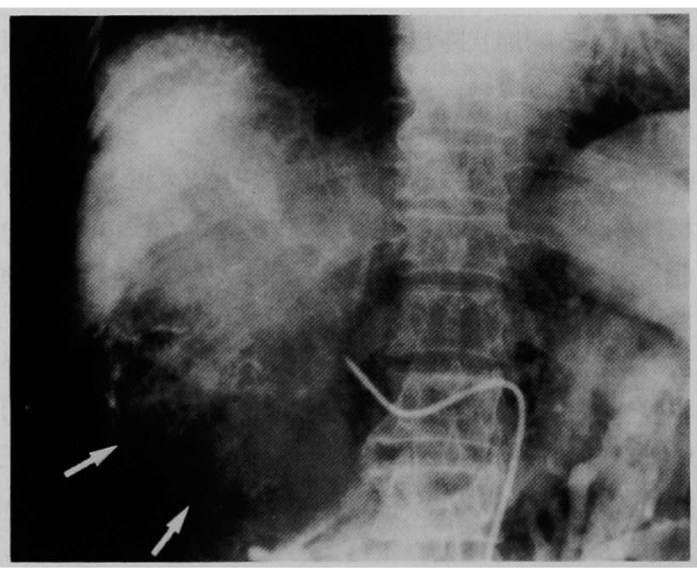

Fig. 4 Capillary phase of selective hepatic angiography shows avascular lesion with a thin wall (arrows) and dense stainning of the anterior segment of the liver due to arterioportal shuntings.

た (Fig. 5).

以上の所見より単発性肝亳胞と診断した。肝包虫症 を除外するために血清学的検索を行なったが，補体結 合反応，間接赤血球凝集反応共に陰性であった。䓂胞 による胆道および門脈系の圧排が認められたこと，画 像診断上，内腔に突出した部位を認め，腫惕性鸾胞が 疑われたことにより，手術適応と判断し，当院第 2 外 科にて手術を施行した。

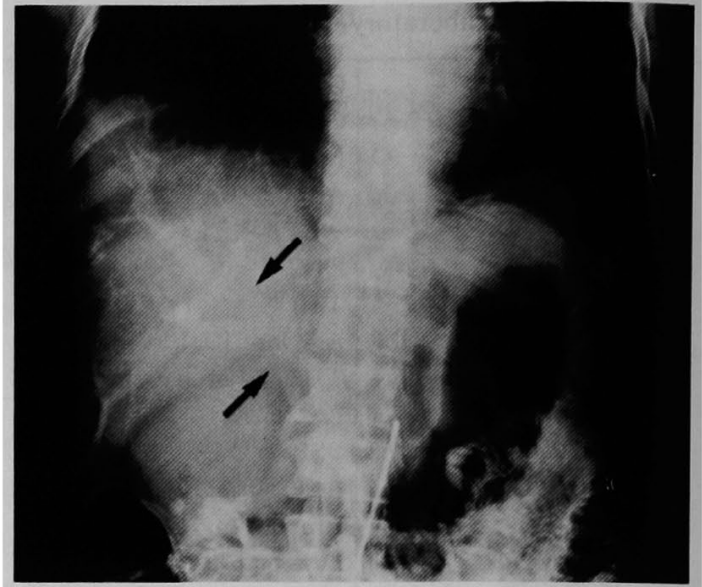

Fig. 5 Portal phase of superior mesenteric angiography shows the compression of the portal vein (arrows) and the anterior inferior branch of the right portal vein is not visualized.

手術所見：腫瘤は肝門部から肝左葉の下面に位置 し， $16 \times 14 \times 12 \mathrm{~cm}$ 大で, 被膜を有し，その表面は平滑 で，約半分は肝実質内に埋没していた (Fig. 6-a). 約 $880 \mathrm{~m} l$ の黄褐色の内容液を有し, 壁には 3 力所の石灰 化部があり，これとは別の部位の内面に， $3.5 \times 2.5 \mathrm{~cm}$ 大の表面顆粒状の隆起を認めた (Fig. 6-b). 同時に摘 除した胆毫内には計18個の胆石を認めたが, 術中胆道 造影では胆管内に結石はみられなかった。

組織学的所見：黄胞内面の顆粒状の部分では, 乳頭 状・䋐毛状の発育バターンを示す高分化型の腺癌がみ られ，高円柱状であり，核の異型，極性の乱れ，核分 裂像が認められた．その他の毫胞壁内面は，活とんど がびらんに陷って怙り，一部残存する被覆上皮は一㸴 の高円柱上皮よりなり, goblet cell を混在し, 内腔に 突出する像も認められた。 また部分的には，良性上皮 から悪性上皮への移行像もみられた．更胞壁は線維性 結合織からなり，間質の細胞成分が密で，一見，卵巣 の間質に類似する部分や，平滑筇細胞の混在する部分 がみられた。 以上より肝震胞腺癌と診断した(Fig. 7). 表胞壁および肝への漫潤は認められなかった。

術後経過：術後第 8 病日には, T. bilirubin 1.38 $\mathrm{mg} / \mathrm{d} l$, AI-P 559IU/L, $\gamma$-GTP 215IU/L, GOT 43IU/ L, GPT 49IU/L と肝機能検查所見の改善がみられた. 術後第16病日に施行した選択的腹腔動脈造影の動脈相 （Fig. 8-a）では A-P shunt が消失し，上腸間膜動脈造 影の門脈相 (Fig. 8-b)では門脈の圧排が解除され，右 


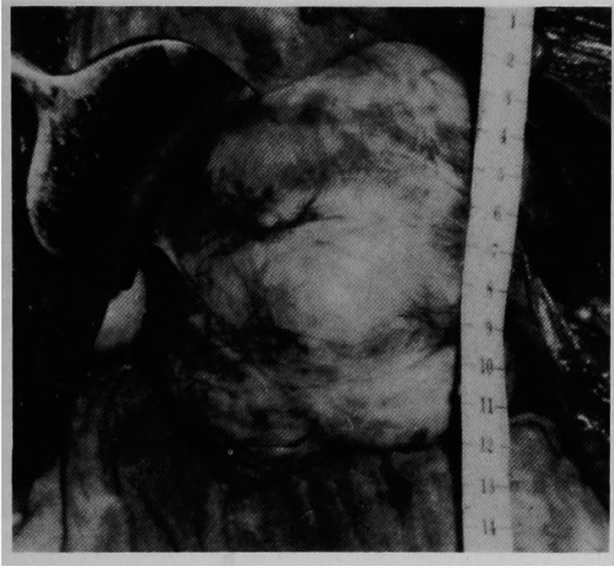

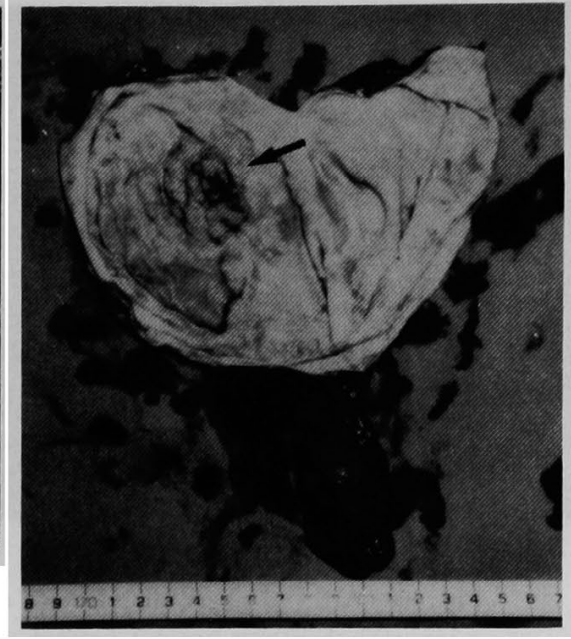

b

Fig. 6a Gross appearance of the cyst at operation.

b. Macroscopic finding of the inner wall of the cyst. The granular lesion is shown (arrow).

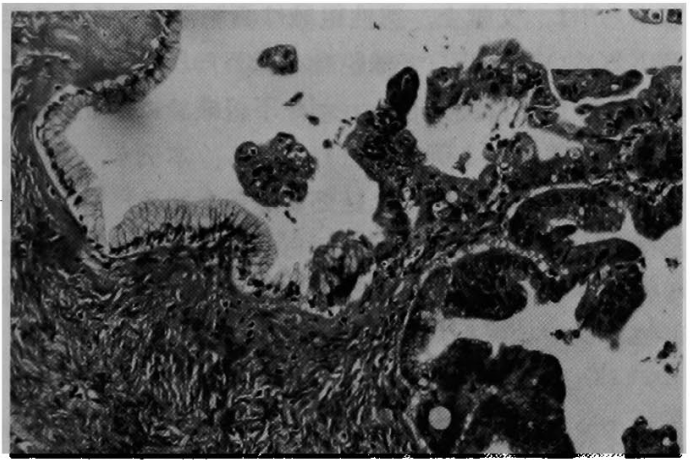

Fig. 7 Microscopic finding of the granular lesion of the cyst wall (H.E. $\times 50$ ).

There is an abrupt transition from the benign columnar epithelium to the malignant papillary epithelium. The stroma is compact and cellular.

前下枝が順行性に造影された。

\section{考案}

肝菉胞腺癌は現在までに約30例が報告されているに すぎず，このうち本邦では1976年の山崎ら7の報告以 来数例をみるのみである。一般に肝の昰胞性疾患は, 臨床症状に乏しく，黄㾞の出現は稀であり，肝機能検 查上特徵的なるのはなく，血管造影上も意胞による血 管系の王排所見を認めるのみである の鑑別は，切除標本あるいは剖㭘材料の検索によらね ばならない場合が多い,10).
本例は肝咅胞としては稀な胆道系酵素の上昇が優位 の肝機能検查異常を呈し，血管造影上，肝末梢部に多 発生した A-P shuntが認められ，腹部エコー・CTに より，術前に腫演性琵胞の可能性が推測された点にお。 いて興味深い。

肝装胞に伴 ら黄疸の報告は少なく，安尾ら 年から75年までの 5 年間で, 本邦においては77例中 2 例に認められたにすぎないと述べている．また Sant$\operatorname{man} 5^{12)}$ は, 間歇的に黄疸を呈した単発性肝莛胞の 1 例を報告し，文献上，肝孪胞100例中で，黄㾝は 3 例に 認められたにすぎず，これらは竞胞による肝外胆道系 の王排により生じた閉塞性黄瘨であったと述べてい る。本例む画像診断にて, 肝内胆管の拡張所見が認め られ，菓胞摘出後に訮機能検查所見が改善したことよ り，顕性黄疸は認められなかったものの，この肝機能 検查異常は，同様な機序により生したたのり考えられ る.

次ぎに，各種肝疾患において，血管造影上認められ る A-P shuntに関しては，Bookstein ら ${ }^{13)} は ，$ 肝硬変 で 0 32\%, 肝細胞癌で $25 \%$, 転移性肝癌で 5 10\% に認められると報告し，その機序として, “transsinusoidal shunt"と“transvasal shunt”の 2 つを挙げ ている. “transsinusoidal shunt”は, 肝静脈の血流障 害に起因する類洞内圧の上昇により生ずる A-P shunt であり, 肝硬変, Budd-Chiari 症候群などでしばしば認 められると述べている. 一方, “transvasal shunt”は 


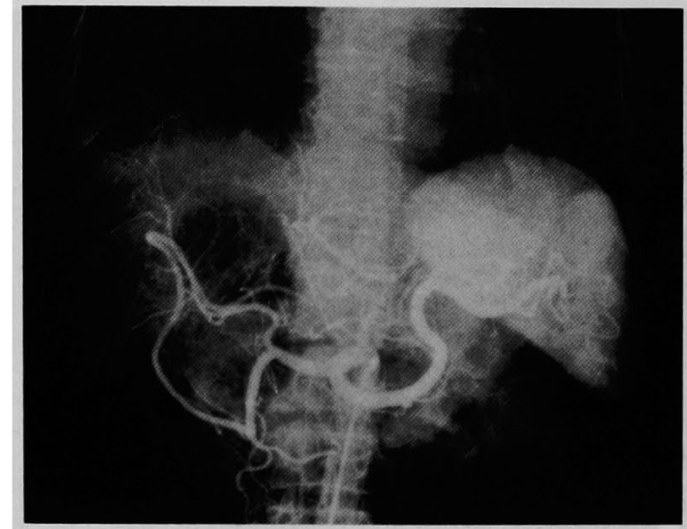

$\mathbf{a}$

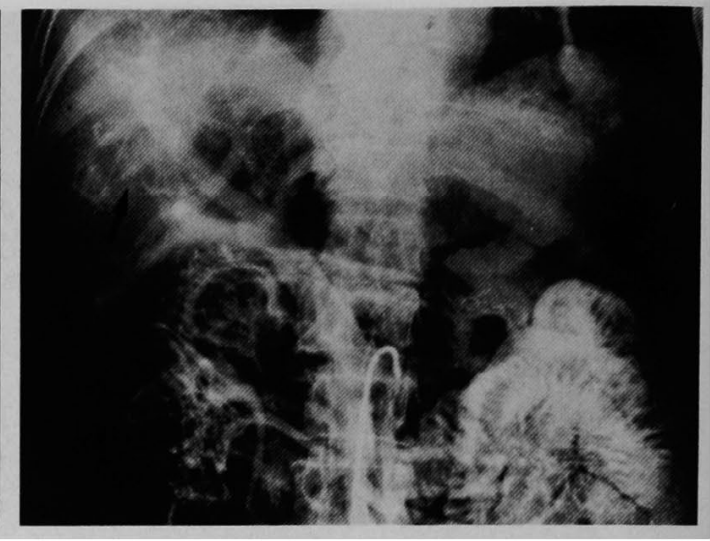

b

Fig. 8a Arterial phase of selective celiac angiography after operation. Arterioportal shuntings are not present.

b. Portal phase of superior mesenteric angiography after operation. The portal vein compression is removed and the anterior inferior branch of the right portal vein is visualized anterogradely (arrow).

“vasa vasorum”を介して生ずる肝動脈から門脈への 直接的な短絡であり，肝動脈血流が遮断され，この部 位より末梢への酵素供給が門脈を介して行なわれる必 要がある場合, あるいは, 門脈が閉塞され,これより 末梢の血流が肝動脈血により保たれる必要が生した場 合などに認められるとしている，前者は転移性肝癌, 肝動脈栓塞術後など, 後者は門脈血栓, 肝細胞癌など で認められると述べている。本例では，術前の血管造 影で咅胞による門脈の王排が認められ, 術後, 門脈圧 排の解除に伴いA.P shunt が消失したことより，この A-P shunt は雴胞の門脈への压非が原因であろらこと は容易に推测されるが，血管造影上は，“transvasal shunt”を示す所見はなく, “transsinusoidal shunt”に よると思われる末梢での多数の A.P shunt が認めら れた.松井ら(4)は，腫旼により閉塞された門脈枝の末梢 に, 選択的肝動脈造影で限局性の濃染像がみられた 9 症例のうち，2 例で明らかに末梢での A-P shunt を認 め,この譏序として, 門脈血流の低下を補ら肝動脈血 流の增加に起因する“transsinusoidal shunt”を挙げて いる. したがって本例にみられた A-P shunt b, 松井 らの症例と同様な機序で生じたと考えられ, “transsinusoidal shunt”は必ずしる類洞内压上昇をきたす矤 㤩にのみ出現するるのではないと思われる。

一般に，襄胞性肝疾患の良覀性の鑑别は，術前ある いは生前にはかなり困難であるとされており, 襄胞液 の穿刺細胞診も陽性率は必ずしも高いとはいえない。

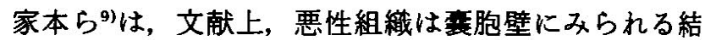
節, あるいはポリープ様組織に認められたと述べ, こ のよらな部位に施行したエコー下組織診により診断し た訮震胞腺癌の 1 例を報告している，本例も，画像診 断にて，内腔に突出した結節状隆起を認め，術中病理 診でこの部位に悪性像が認められており，画像診断は 少なくとも肝霹胞の腫湯性の有無を推定する一助とな り得ると思われる。

おわりに

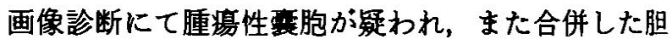
道系酵素の上昇を主とした肝機能検査異常, および A$\mathrm{P}$ shunt が萿胞摘出後に軽减・消失した肝亯胞腺癌の 1 例を経験した. 震胞の鑑別, および巨大萃胞の門脈・ 胆道系への mass effect を考える上で興味深い症例之 考克報告した。

\section{文献}

1) More JRS: Cystadenocarcinoma of the liver. J Clin pathol $19: 470-474,1966$

2) Marsh JL, Dahms B, Longmire WP Jr: Cystadenoma and cystadenocarcinoma of the biliary system. Arch Surg $109: 41-43,1974$

3) Flanigan DP: Biliary carcinoma associated with biliary cysts. Cancer $40: 880-883,1977$

4) Ishak KG, Willis $G W$, Cummins $S D$, et al: Biliary cystadenoma and cystadenocarcinoma : Report of 14 cases and review of the literature. 
Cancer 39 : 322-338, 1977

5) Dean DL, Bauer HM: Primary cystic carcinoma of the liver. Am J Surg 117: 416-420, 1969

6) Kasai Y, Sasaki E, Tamaki A, et al: Carcinoma arising in the cyst of the liver: Report of three cases. Jpn J Surg 7:65-72, 1977

7) Yamasaki I, Tagata $K$, Hamamoto $Y$, et al : An autopsy case of mucinous cystadenocarcinoma of the liver. Yonago Acta Med 20: 142 $-146,1976$

8) Bloustein PA : Association of carcinoma with congenital cystic conditions of the liver and bile ducts. Am J Gastroenterol 67: 40-46, 1977

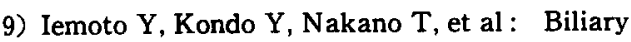
cystadenocarcinoma diagnosed by liver biopsy performed under ultrasonographic guidance. Gastroenterology $84: 399-403,1983$

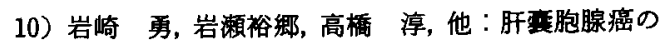
1 剖検例。肝缄 $24: 1446-1450,1983$

11）安尾 信, 池上文詔, 三浦瞵二郎, 他 : 高度の黄㾝 を呈した非寄生虫性多発性肝衰胞症の一例。肝臓 $19: 1171-1176,1978$

12) Santman FW, Thijs LG, vander Veen EA, et al : Intermittent jaundice : A rare complication of a solitary nonparasitic liver cyst. Gastroenterology $72: 325-328,1977$

13) Bookstein JJ, Cho KJ, Davis GB, et al : Arterioportal communications: Observations and hypotheses concerning trannssinusoidal and transvasal types. Radiology 142 : 581-590, 1982

14) Matsui $O$, Takashima $T$, Kadoya $M$, et al: Segmental staining on hepatic arteriography as a sign of intrahepatic portal vein obstruction. Radiology 152 : 401-406, 1984

\title{
A case of biliary cystadenocarcinoma with multicentric arterioportal shuntings that disappeared after total excision of the entire cyst
}

\author{
Fumiaki Matsushita, Hitoshi Yokoyama, Masashi Unoura, Nobuyoshi TaNaKa, \\ Yasuhiro Kato, Kenichi KobaYashI, Nobu HatToRI*1, Yasuzi SHINMURA*2, \\ Masumi Kadoya, Osamu Matsui*3, Yuzi MizUKami*4 and \\ Yasuni NAKANUMA*5
}

A 53 year-old woman was admitted to our hospital because of skin itching. The liver function tests revealed the marked elevation of Al-P and $\gamma$-GTP. Ultrasound and CT scan showed a huge liver cyst with a mural nodular lesion and dilated intrahepatic bile ducts. Angiography showed the compression of the portal vein and multicentric arterioportal shuntings in the peripheral region of the liver. The histological finding of the cyst was biliary cyst adenocarcinoma. After the excision of the cyst, the level of Al-P and $\gamma$-GTP was decreased, and the disappearance of the portal vein compression and arterioportal shuntings was shown by angiography. In this case, a huge liver cyst caused the compression of the biliary and portal system, resulting in the obstructive pattern on liver function tests and arterioportal shuntings of transsinusoidal type. Ultrasound and CT scan were useful to detect the neoplastic finding in this liver cyst.

*1 The First Department of Internal Medicine, School of Medicine, Kanazawa University (Kanazawa)

*2 The Second Department of Surgery, School of Medicine, Kanazawa University

*3 Department of Radiology, School of Medicine, Kanazawa University

* Central Clinical Laboratory, Kanazawa University Hospital

${ }^{*}$ The Second Department of Pathology, School of Medicine, Kanazawa University 